\title{
Problems of Sick Industries - Bangladesh Perspective
}

\author{
A.K.M. Solayman Hoque ${ }^{1 *}$ and S.K. Biswas ${ }^{2}$ \\ ${ }^{1}$ Bangladesh Steel and Engineering Corporation, Dhaka, Bangladesh \\ ${ }^{2}$ Department of Mechanical and Production Engineering \\ Ahsanullah University of Science \& Technology, Dhaka, Bangladesh \\ *Corresponding e-mail: solaymanhoq@gmail.com
}

\begin{abstract}
The problem of industries becoming sick in recent years, both in public and private sectors in Bangladesh and also in some cases in some other developing and underdeveloped countries, has turned to be alarming. Although the causes for closure or divestment might be many but in most of the cases continued loss played a major role in industries becoming sick. Thus the problem of industries becoming sick deserves to be treated more seriously at Government policy level, and also by the researchers in academic and industrial arena, as it is related to the economy and development of a country. Every industry can be seen as a system working in diversified environment. It operates under the influence of many external and internal factors. Various combinations of external and internal factors are responsible for industries to becoming sick. But these too vary from country to country, economy-to-economy, etc. It can be said for surely that the causes for industries becoming sick shall not necessarily be similar in under-developed, developing and developed countries. In this paper an attempt has been made to identify the causes of industries becoming sick in Bangladesh and to show how far the application of the theories and principles of Production and Operations Management play a role in the prevention of industries becoming sick. No attempt has been made here to discuss and even to analyze the causes for industries becoming sick related to industrial policy of the country, legal and other related rules and regulations, industrial competitions, influence of local politics, open market economy, etc.
\end{abstract}

Keywords: Sick Industry, Industrial Engineering, Production and Operations management.

\section{INTRODUCTION}

There were only few industries in this region, presently known as Bangladesh, before 1947. Industrialization started at a slower pace after 1947 i.e., after the birth of the then East Pakistan from the British rule. Many of the heavy industries, particularly under public sector, were established during the period of sixties. Some industries in private sector on cotton, jute, and consumer goods etc., typically known as small and medium scale (SMS) industries were also established during the period of fifties and sixties. After the birth of Bangladesh in 1971, some heavy industries on agricultural fertilizers, steel, energy, etc. were established. Due to the availability of cheap labor, establishment of export processing zones and BSCIC (Bangladesh Small and Cottage Industries Corporation) industrial areas, many garments, ceramic, pharmaceutical, and other small scale industries (SSI) have been established in the last 23 decades. Some foreign investors too made industrial investments in the last 2 decades. Just after independence of Bangladesh, some industries owned by private owners were taken over as nationalized industries.

Many industries, both in government and private sectors, have been closed down one after another due to many uncontrollable factors especially in the last few decades. It was known that before the closure of these industries obviously they became sick, and they tried to overcome the causes of sickness and being failed had been closed down. Bangladesh has experience of closing down of some of her heavy industries like Machine Tools Factory at Joydevpur, Chittagong Steel Mills, Adamjee Jute Mills, etc. Industries becoming sick have become an acute problem in Bangladesh in the recent years. Statistics shows, in 1991 government first declared 1581 industries as sick ${ }^{1}$. After the birth of Bangladesh, industrial sector inside the country faced many problems. Government nationalized many industries and conditions of many nationalized industries deteriorated soon probably due to many uncontrollable factors like absence of motivational problems, corporate industrial policy and absence of strict supervision, etc. Thus many industries were sold out or closed down. Table-1 shows the industrial scenario in Bangladesh in the last two decades $^{2}$

\section{WHAT DOES 'THE SICKNESS OF INDUSTRIES' MEAN ${ }^{3,4,5}$}

People become sick and industries also become sick. Sick people suffer from various problems and if this sickness continues sometimes the life becomes threatened. If proper care is taken, people can recover. Similar is the case with industries. In underdeveloped or developing countries, the term 'Sickness of industries' has become a buzzword at 
present; particularly in industrial sectors. It has become a cause of concern to investors, entrepreneurs and shareholders, policy makers, even to the government and also to the society in general. If industries become sick, money and time are wasted; it brings down adverse effect on economy and also social problems in various dimensions surface. So, national economy of developing or underdeveloped countries cannot afford this large-scale wastage of wealth due to industries turning sick.

Table 1. Status of industries under Sector Corporations of Bangladesh

\begin{tabular}{|l|c|c|}
\hline \multicolumn{1}{|c|}{$\begin{array}{c}\text { Name of the } \\
\text { corporation }\end{array}$} & $\begin{array}{c}\text { Total } \\
\text { numbers of } \\
\text { established } \\
\text { industries in } \\
\text { '70s }\end{array}$ & $\begin{array}{c}\text { Presently } \\
\text { owned by } \\
\text { the } \\
\text { corporation }\end{array}$ \\
\hline $\begin{array}{l}\text { Bangladesh Jute } \\
\text { Mills Corp. } \\
\text { (BJMC) }\end{array}$ & 77 & 23 \\
\hline $\begin{array}{l}\text { Bangladesh Textile } \\
\text { Mills Corp. } \\
\text { (BTMC) }\end{array}$ & 72 & 21 \\
\hline $\begin{array}{l}\text { Bangladesh Sugar } \\
\text { and Food } \\
\text { Industries } \\
\text { Corp. (BSFIC) }\end{array}$ & 54 & 14 \\
\hline $\begin{array}{l}\text { Bangladesh Steel } \\
\text { \& }\end{array}$ & 54 & 12 \\
$\begin{array}{l}\text { Engineering Corp. } \\
\text { (BSEC) }\end{array}$ & & \\
\hline $\begin{array}{l}\text { Bangladesh } \\
\text { Chemical } \\
\text { Industries } \\
\text { Corporation } \\
\text { (BCIC) }\end{array}$ & 13 & 13 \\
\hline
\end{tabular}

It is generally said that an industry is sick if it cannot pull on its normal activities, suffers continuous losses or if the gradual wiping out of its capital starts. A sick industry is one whose financial viability is threatened by adverse factors.

Many authors defined industries falling into sickness in many ways. As per financial bill of India, 1977, a sick industry is one whose 50 percent or more of capital reserve were wiped out by the losses [5].

R.V. Raman [3] summarized the causes of industries becoming sick as (i) when the company has negative working capital and the unit continues to make loss, (ii) cash inflow during the last 3 years has been progressively going down in relation to revenue commitment, (iii) cumulative loss exceeds capital and reserve and (iv) when cash inflow is less than the operational commitment and inadequate for debt servicing.
Many similar definitions are now available in related literatures. So it can be said that if an industry cannot perform its normal activities like purchasing of materials and other resources, can not manage the required fund to run business, fails to generate surplus and remains dependent on external funds for survival, the concerned industry can be considered as a sick one. If this sickness persists for a few years, it is forced to close down. Then financial institutions or the concerned organizations come forward to recover at least some part of the money invested or given as loan. And if it is a government owned industry, government starts processing to close it down or to sell it to private parties or gives option for BMRE (Balancing, Modernization, Rehabilitation and Expansion).

It can be mentioned here that, in some cases, economically viable nationalized industries (by some opinion) too were declared as sick and the same have been handed over to private sector in later years. Moreover denationalization of industries too took place, due to government policy, in some cases.

\section{CAUSES OF SICKNESS ${ }^{3,4,5}$}

An industry might face various problems since its establishment or at early stages of life and sometimes the problems persist as the industry moves forward through the future. Problems may be classified as internal or external or can be classified as financial, technological, environmental, management and marketing related etc. This grouping and sub-grouping of problems can be extended. Whichever be the root causes, they too differ according to the type, location and also on the availability of co-operation and noncooperation of financial, governmental and other related agencies, organizations or institutions. The authors think that if the factors of production i.e., Man, Machine and Material (the famous 3 M's) and in addition Management, Money, Method and Marketing (other 4 M's) are not properly managed various problems might arise. The authors think that these factors are interrelated and the very survival of the industry might be dependent on factors related to these. Thus, we can classify causes for industries to become sick as:

1) Management related: (relating to all general management activities, personnel management activities, marketing management activities, etc.,)

a) Improper strategic management policy, lack of proper mission and vision, inability to define clearly the present position and final goal, determination of inappropriate path to reach final goal,

b) Lack of proper experience and business outlook of entrepreneurs, investors, decision makers, 
etc,

c) Improper manpower planning, over employment and under employment problems,

d) Lack of proper training, education, experience and challenging drive force of managers or CEO's,

e) Improper organizational structure, absence of reorganizing process with change in business dynamics,

f) Poor managerial or administrative control,

g) Lack of continuous tracking of productivity indices and also lack of continuous tracking of forecasted and actual demands or sales,

h) Inappropriate handling of personnel problems including CBA, motivational and labor related problems, in some cases managers do not behave like leaders,

i) Lack of proper market planning, market survey, defective or improper sales promotion activities, defective pricing policy, in some cases problem with recovery of selling cost of products sold on credit etc.,

j) Conservative attitude of managers: new manager in many cases do not try to take initiative or do not try to take risk to deviate from what was in the past and i.e., usually they do not try to test anything new,

k) Improper (of course in some cases) delegation of authority and absence of accountability,

1) Non-availability of skilled labor force and management personnel,

m) Absence of well-developed organizational culture, etc.

2) Financial: (relating to money)

a) Poor financial management policies,

b) Poor working capital management,

c) Improper managing of accounts,

d) Non availability of timely decisions from government, banks, financial institutions,

e) High interest rate on loans,

f) Improper tracking of financial positions, time delay of adjusting to changed local, global economy and business environment prevailing outside,

g) In some cases incorrect analysis and decision making with respect to product diversification, divestment,

h) Incorrect financial analysis for investment, replacement of plants and machineries, etc.

i) Non application of Financial Ratio analysis, Product life cycle graph, Time value of money principles, etc.

3) Technological: (relating to production)

a) Improper location, layout and material handling system design decision and defective project planning,

b) Use of defective forecasting data, use of inappropriate forecasting method,

c) Improper capacity planning,

d) Improper inventory management and improper supply chain management,

e) Absence of application of Technology Management Principles,

f) Inadequate application of quality control techniques and delay in adaptation to latest quality management tool like Total Quality Management (TQM) and Quality Assurance programs,

g(i)) Absence of use of scientific methods in Scheduling (Determination of Master Production Schedule (MPS)) and in Production Planning, etc,

(ii)) Non application of MRP. JIT principles even if they are needed

h) Improper application or non-application of decision and optimization theories, etc,

i) Improper process planning, absence of application of motion and time study, and ergonomic principles,

j) Non-application of 'Reengineering' principles so as to adjust to the changed situation, etc.

k) Or even not trying to adopt to "Reverse Engineering Principles" when technical knowledge to develop a new product/process is poor.

4) Environmental:

a) Change of local and global economic conditions, changes in money exchange rates, etc,

b) Lack of coordination between various ministries and government departments and delay in getting decisions,

c) Frequent changes in government policies with respect to investment criteria, tax determination, import and export policies,

d) Non-availability or irregular supply of required energy (electrical energy, gas), raw materials, labor force, etc.

e) Losses due to Strikes and other political and social problems,

f) Occurrence of Natural calamities like cyclone, flood, tornado, tsunami, etc.,

g) Attitude of mass media, etc,

h) Change of Technology and its lifetime, etc.

Although many factors have been listed above, and even the list can be extended further, in actual situation a few or some, not all, play the main role in turning an industry to become sick. It is said that Chittagong Steel Mills ltd became sick due to some unavoidable causes and it is reported that among those liberalization of import policy of the country at that time, continuance of excess manpower (improper personnel management policy) even when production declined, failing to compete in market (absence of proper marketing management 
policy) are a few to be mentioned although there might have many more important factors for the sick condition that occurred and persistently prevailed.

\section{SYMPTOMS TO BECOMING SICK ${ }^{3}$}

Some industries grow born sick, some are made sick and some can be classified as thrust sick. Born sick industries are those that are established with unclear vision, inaccurate forecasting of market, defective appraisal, implementation and planning policies. Industries are made sick by the inefficient management, lack of dynamism, absence of effective monitoring, delay in adopting preventive measures to avoid sickness. Environmental factors produce thrust sick industries ${ }^{5}$.

Whatever be the causes of sickness, some of the symptoms of industries becoming sick can be taken as follows :

1. Reduced working capital, fall in sales/profit, rapid increase of debtors, frequent liquidity problems, wiping out of capital reserve,

2. High managerial and labor turnover, labor unrest,

3. Rise in complaints from staffs and customers,

4. Unfavorable market development,

5. Rise in finished product inventory,

6. Decline in productivity,

7. Difficulty in paying salaries, bills loans, taxes, bank interests, etc.

Performances of some of the industries of BSEC (Bangladesh Steel Engineering Corporation) \& BCIC (Bangladesh Chemical Industries Corporation) have been studied based on actual past data obtained from the brochures of $\mathrm{BSEC}^{6,11}$, and BCIC and also from other sources ${ }^{12}$

Following graphs showing Industry performance (revenue earning or quantity produced) against time (from FY 2005-'06 to FY 2010-'11) for 9 industries and for Bangladesh Machine tools Factory Ltd for FY 1985-'86 to 1993-'94, will reveal that out of six industries two BMTF (Bangladesh Machine Tools Factory) and CSM (Chittagong Steel Mills) showed clear symptoms of sickness before they have been closed down. The causes of the closer of these two industries as could be collected from reports ${ }^{11,6}$ can be as follows. Actual data for two industries used to draw graphs are shown in the Appendix $1 \& 2$, the related data for other 8 industries considered can be found in 6,11,12 which have not been shown in Appendix.

\section{Chittagong Steel Mills Limited (CSM)}

Chittagong steel mills became a losing concern before closer ${ }^{6}$. It was having continuous loss since 1989. i.e., its average revenue had been decreasing continuously. The following causes might be attributed to that situation

1. Over employment,
2. Cost of product was too high,

3. Over estimation of market demand,

4. Inventory was too high,

5. Political and labor unrest,

6. Frequent changes in govt. policy (At that time Govt. abolished the direct procurement method )

7. Interference of $\mathrm{CBA}$ in day to day administration, etc.

\section{Bangladesh Machine Tools Factory (BMTF)}

Bangladesh Machine Tools Factory at Joydevpur, became a losing industry since 1990. Its revenue earning had been decreasing in last six years since 1990. The cause of decline in revenue earning might be attributed to:

1. Improper utilization of production capacity,

2. Lack of demand of their products,

3. Inventory was too high,

4. Improper manpower planning.

5. Improper marketing policy (Lack of publicity campaign through TV, Radio, Press etc. for popularizing the products) .

6. Shortage of working capital.

Collected data shows conditions of two other industries (Pragoti Industries and GEM Co. (General Electric Manufacturing Company) were not also good and they had every symptom of becoming sick, during the period data was taken. These two industries, therefore, deserve attention of policy makers and preventive measures are needed to be taken immediately to avoid closure or of being handed over to other owners.

\section{General Electric Manufacturing Co. Limited (GEM Co.)}

GEM Co. at Patenga, Chittagong, remained as a losing industry. It has been continuously giving loss from FY 1998-99 to FY 2010-11. Though the production and sales became better than the previous year but anyway this industry has been fighting to survive for long particularly since after establishment. The causes of decline in revenue earning can be due to:

1. Shortage of working capital,

2. Raw material scarcity,

3. Faulty project planning and appraisal methods,

4. Higher rate of interest on bank loan,

5. Non-receipt of sufficient purchase order,

6. Raw material stock was too high in $1990-91$.

\section{Pragoti Industries Limited (PIL)}

The performance of Pragoti Industries at Sitakunda, Chittagong, was not good enough in six years (i.e., from FY 2001-02 to FY 2005-06). Pragoti Industries limited has become a profitable organization since FY 2006-2007 due to the some government decision. The causes of decline in revenue earning or profit earning at the beginning might be attributed to : 
1. Lack of demand of assembled Bus, Jeep, Truck etc. (FY 2001-02 to 2006-07),

2. Higher rate of interest on bank loan,

3. Change in global and local condition,

4. Frequent change in govt. policies (Tax determination, import / export policies, import liberalization)

5. Operational loss increases due to sales volume decline during FY 2001-02 to 2006-07.

The other two industries named Gazi wires ltd. and Eastern Cables ltd. are fighting to remain in business but the present trend cannot be considered as satisfactory one. These two industries too deserve attention to avoid future catastrophe.

\section{Gazi Wires Limited (GWL)}

It may be said that the authorities of the Corporation generally do not consider that Gazi wires limited, at Kalurghat, Chittagong is not a losing industry in general but collected data show the overall condition of production, sales and profits are not that good to mention about. The amount of profit is poor in every year. The causes of inefficient operational activity might be due to :

1. Shortage of working capital,

2. Marketing activities is poor,

3. Operational loss due to low sales volume.

\section{Eastern Cables Limited (ECL)}

Corporation authorities also do not consider that Eastern Cables Limited, at Chittagong, is not a losing industry in general but the overall condition of the industry is not good at all. The causes of poor performances may be due to:

1. Lack of demand of their products,

2. Frequent power disruption,

3. Acute competition with products imported under open market policy, duty and tax anomaly.

Now we would like to present the scenario in 4 Industries of BCIC (Bangladesh Chemical Industries Corporation). Although CUFL's (Chittagong Urea Fertilizer Ltd) general condition was becoming gradually worse but suddenly the condition improved a bit, so it deserves careful administrative attention if it wants to go out of really bad overall condition. The other three industries (Urea Fertilizer Factory Limited, Chatak Cement Company Limited, Natural Gas Fertilizer Factory Limited) are showing some signs of becoming sick in recent time and they too deserve careful attention.

\section{Chittagong Urea Fertilizer Ltd.(CUFL):}

Chittagong Urea Fertilizer Ltd, at Anwara, Chittagong, is also a losing factory. It is having loss from FY since 2004-05 till today except in FY 2008-09, The causes of this condition may be attributed to :
1. Scarcity of gas supply (Due to govt. decision in June, 2010)

2. Average import price of urea is too high compared to that of the production $\operatorname{cost}($ To meet the countries demand fertilizer factory needs to import urea)

\section{Urea Fertilizer Factory Limited}

Urea Fertilizer Factory ltd. at Ghorasal, became a losing factory. It was having loss continuously from FY 2003-04. Its bad performance due to:

1. Scarcity of gas supply (As per govt. decision from $1^{\text {st }}$ April to $30^{\text {th }}$ June 2010.),

2. Natural calamities.

3. Lack of proper education, training \& experience (Accident occurred in ammonia plant compressor house in 12-08-2007).

\section{Chatak Cement Company Ltd. (CCC)}

Collected data shows Chatak Cement Factory at Chatak Upazilla, is a losing factory too, it is giving loss continuously from FY 2003-04. Besides sudden rise in revenue earning in FY 2007-08. Its performance cannot be said as good, whose causes might be :

1. Quantity of production is less than the set target,

2. Marketing problem (Dealer did not lift/ receive their allocated amount),

3. Frequent power failure,

4. Keeping old machineries \& technology,

5. Sales problem due to heavy rainfall,

6. Disturbances in production due to shortage of space,

7. Occurrences of natural calamities like rainfall, cyclone, etc.

\section{Natural Gas Fertilizer Factory Ltd. (NGFL)}

Natural Gas Fertilizer Factory at Sylhet, became a losing factory, besides its sudden rise in FY 2008-09. It is having loss continuously from FY 2003-04 and its revenue earning also declined during the period. Such situation might be due to :

1. Scarcity of raw material,

2. Power failure,

3. Old Machineries \& technology.

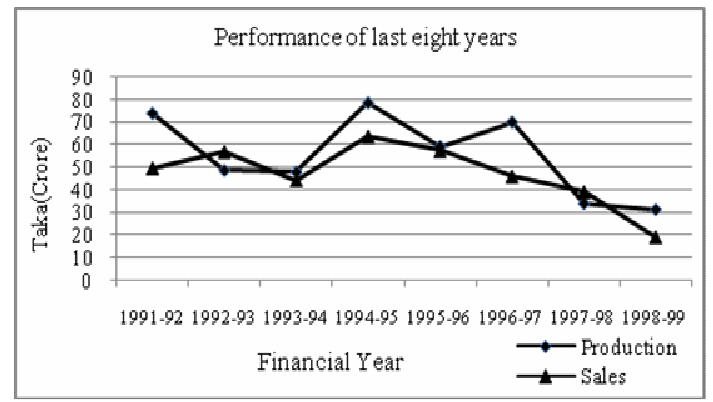

Figure 1. Performance of Chittagong Steel Mills Ltd 


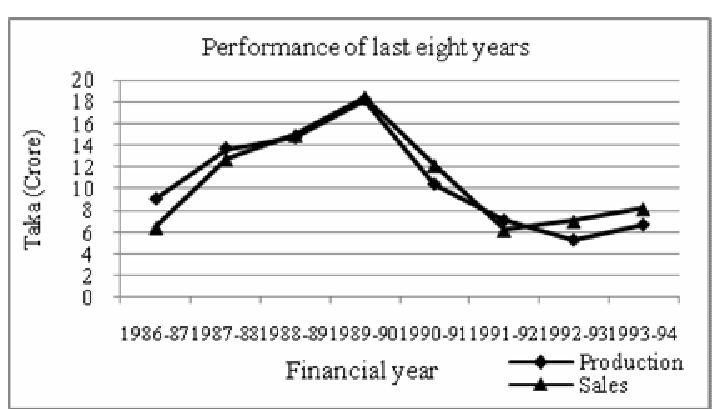

Figure 2. Performance of BMTF

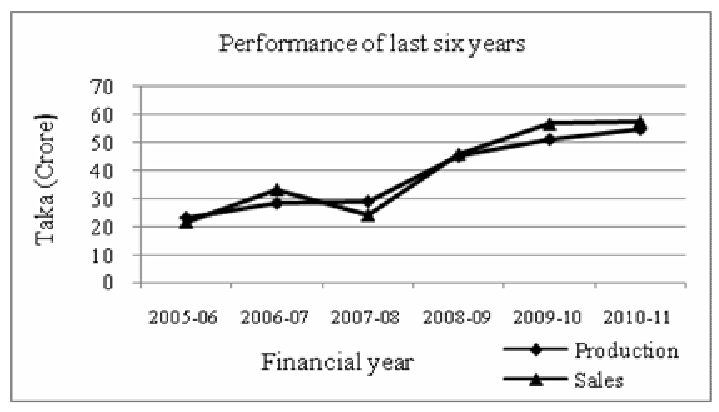

Figure 3. Performance of GEM Co. Ltd.

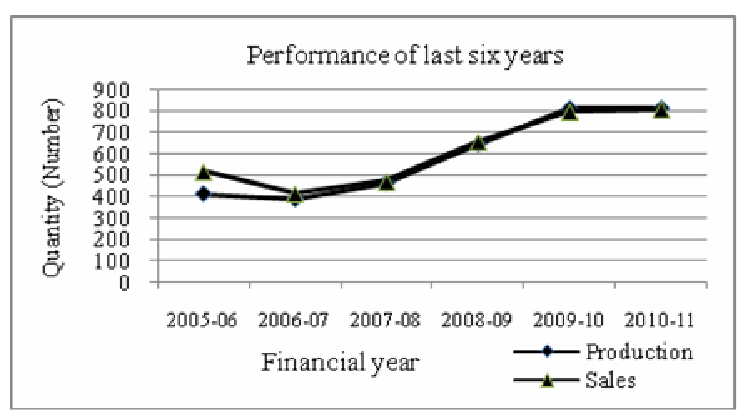

Figure 4. Performance of Pragoti Industries Limited.

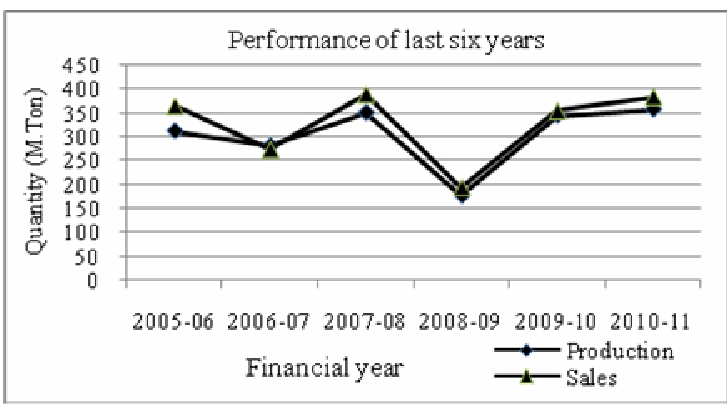

Figure 5. Performance of Gazi Wires Limited

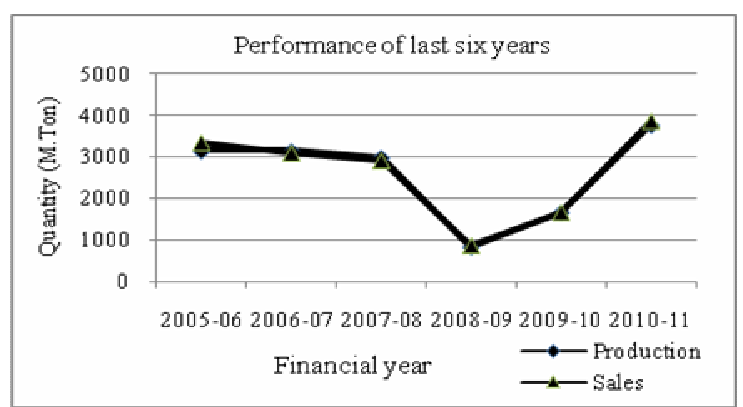

Figure 6. Performance of Eastern Cables Limited

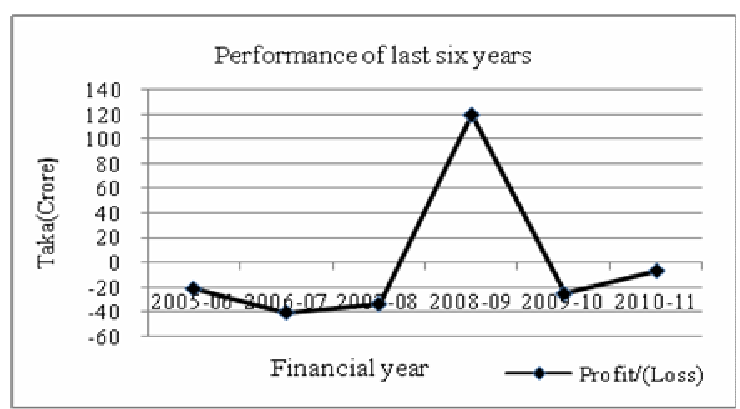

Figure 7. Performance of CUFL

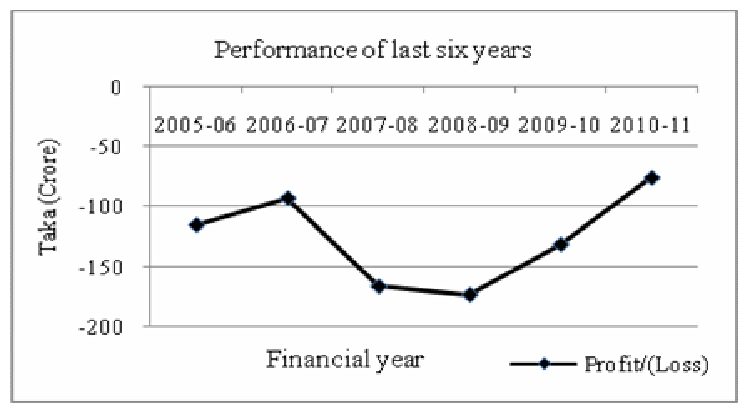

Figure 8. Performance of Urea Fertilizer Factory Ltd.

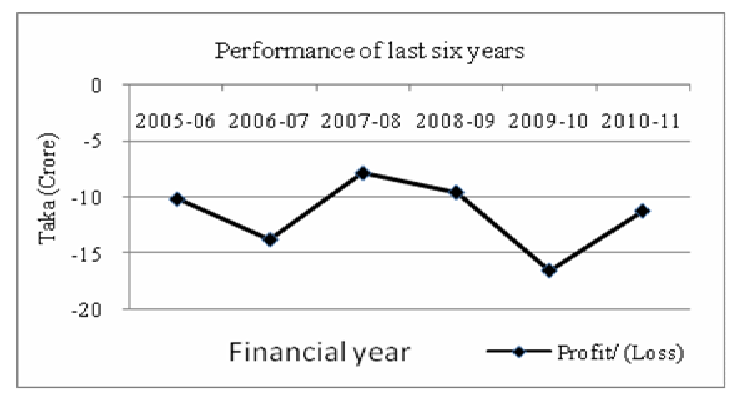

Figure 9. Performance of Chatak Cement Company Ltd 


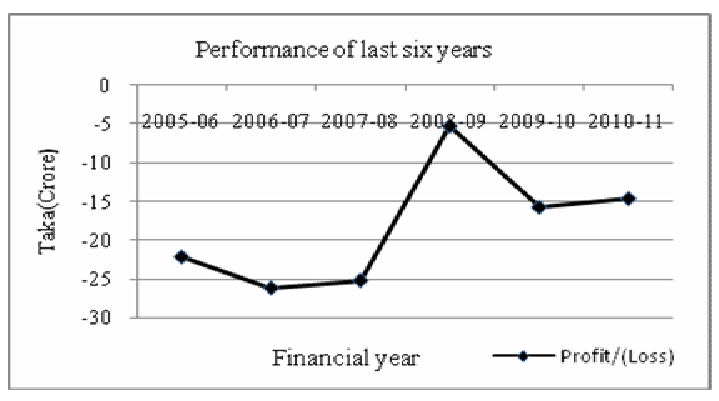

Figure 10. Performance of NGF Factory Limited

\section{IMPACT OF TECHNOLOGICAL FACTORS ON SICK INDUSTRIES ${ }^{6 \sim 10}$}

It is sometimes possible to solve many of the management and financial related problems if proper care is taken and proper planning is done. On environmental factors the industry has either no control or limited control. We think technological factors play a major role in industries becoming sick. Many of the technological factors can be solved if the problems are given due importance. Qualified technical persons should be entrusted with the job of solving the technological problems using standard established methods. The concepts of F.W. Taylor's scientific management theory and other management theories of the pioneers, of 'Management Thoughts', should not be forgotten. Also proper emphasis should be given to solve the problems of motivation of employees.

Continuous loss, decline in production and profit and problem of working capital management are some of the main symptoms of industries becoming sick. If inventory management or supply chain management system is not properly practiced, then sizable portion of the working capital becomes blocked. If the application of the production planning and control system is inefficient, then production cost increases and thus loss increase, profit and also productivity declines. Effective capacity and manpower planning, efficient Master Production Schedule, efficient process design etc. should be given more importance to overcome problems relating to efficient running and to minimize loss.

In most of the papers on Sick Industries, management, marketing, environmental and finance related problems have been discussed. But the real horse behind the scene, the efficient and effective production methods, has been seen to be given less importance sometimes. In the following, the effects of some of the important technological factors are discussed ${ }^{7-10}$.

\section{Location, Layout and Material Handling}

Selection of proper location, layout and use of efficient material handling system is directly related to the cost of the product. If products become expensive in relation to those of competitors, and along with that if efficient marketing policy is not practiced, it is difficult to survive in the market for long time. Chittagong steel mills experienced that. It is said that sometimes material-handling cost go even up to $30 \%$ of the cost of production due to inappropriate layout and material handling system design. Design of best layout and best material-handling system reduces production cost and proper location reduces transportation cost, ensures availability of manpower and other factors of production.

\section{Inventory and supply Chain Management}

Inventory eats up the working capital. Excess inventory does not bring to surface the problems related to production. The supply chain is the network of organizations that are connected through upstream and downstream linkages, in the different processes and activities that produce value in the form of products and services to the ultimate customers [8]. Effective use of supply chain reduces uncertainties of supply of quality raw materials for production as well as in delivery of quality products to the users. The concept though not very old, can be used to reduce the possible causes of sickness due to procurement and supply of product.

\section{Technology Management ${ }^{9}$}

Every technology has its own life cycle. Before making investment in an industry and even after establishment, technology forecast is vital as it is correlated to the very survival of the industry. In this age of competition if any industry wants to survive, it must recognize the dynamic process of change of technology.

\section{Total Quality Control (TQM) and Quality Assurance}

The philosophical concept of involving everybody, in the organization and in the supply chain, with an aim to improve the quality by trying to accommodate all types of opinions, helps in quality improvement which ultimately ensures customers' confidence. TQM concept also brought the concept of elimination of all types of wastes through the implementation of just in time [JIT] (Lean Manufacturing) philosophy. TQM with quality assurance program like ISO certification prevents the loss of customers.

\section{Re-engineering and Reverse Engineering ${ }^{10}$}

Any established method of production, layout and other planning and control activities, might not remain good or appropriate with the dynamic characteristics of various activities, technology change, new invention etc. Thus forgetting about 
conservative idea of not taking risk, appropriate changes are to be made wherever necessary to remain in completion. Competitive advantage must be given due consideration always. And thus principles of 'Re-engineering' must be followed whenever it is necessary. It is sometimes true that in the initial stage all industries in $3^{\text {rd }}$ world countries might not have all necessary expertise with respect to Product design and Process design. In that condition "Reverse Engineering" method is followed so as to produce products as done in "Benched Marked" industries until the industry itself become capable to make or do by itself.

\section{Ergonomics and Motion and Time Study}

Products and processes are to be designed by considering the users' characteristics, health and safety measures. Many of the health related problems of workers are related to ill design of product or process. Nonconformities in manmachine system, give rise to health problems, accidents and even bigger catastrophe. This ultimately increases the costs of health insurance, health service and compensation. Costs are also increased through high labor turnover ratio.

Motion and time study is required to find out the best method and best time of doing a job. As product cost is directly related to time involved, so, the required time is to be made optimum by using best method and using ergonomic principles.

\section{Capacity, Manpower Requirement Planning and Aggregate Planning}

Capacity planning is central to the long-term success of the organization. Too much capacity can be as agonizing as too little. Mangers face problems of deciding: should we have one large facility of several small ones? As the decision is related to the performance of the organization, scientific answer is to be found out. Manpower, one of the 3 M's (Man, machine and Material) of production, is to be planned so as to keep their level at optimum. Manpower requirement declines if sales declines and vice-versa. Keeping constant number of manpower involves money, increases production cost and other related costs. In USA hire and fire system is well known. It is difficult to apply this in every situation and in every country having various social thinking. It is a problem to apply that principle especially in local public sector industries. American companies adjust manpower as per requirement although this is not always true in the case of Japan, in many cases, where utilization of excess manpower is being used to do other jobs if production declines. Even in USA, through reorganizing process, sometimes levels in organization are reduced; departments are merged to bring back efficiency and dynamism resulting in decrease in manpower. Although difficult to implement, for the very survival of the industry, this too requires to be practiced if necessary. So practice of proper man-power planning and aggregate planning is essential. It is reported that Both BMTF (Bangladesh Machine Tools Factory) and Chittagong Steel Mills suffered from over manpower problem before their closure.

\section{Scheduling and production planning}

Determination of Master Production Schedule (MPS) and adjustment of schedule with the change of orders received, play an important role in determining the target supply date, which in turn is related to customers satisfaction. Customer is the focus of modern marketing concept. So appropriate scheduling and production planning is related to better performance of industries. Tested methods of MRP, JIT, Lean manufacturing should be followed in applicable cases.

\section{Optimization Principles}

Various optimization principles were developed during World War II. Use of the optimization principles brought benefits in war planning and ultimately in many cases money had been saved and operational efficiency could be ensured. We think, use of these, optimization techniques in decision-making, tools might help managers in managing the operational affairs and efficiencies in more effective ways.

\section{Productivity Analysis and Planning}

Productivity is related to the performance of the industry. In a word, increase in productivity means better performance of the industry. Many factors: e.g., technology related, man related, product related, and production related, etc., affect productivity. Continuous improvement of productivity is to be tried through continuous analysis and monitoring for the very survival of the industry/firm.

In the above, it has been tried to show the relationship of production planning and control activities with the problems of industries becoming sick. Industries start to become sick when its productivity declines; part of working capital is blocked along with various other problems. Proper use of the methods described above will definitely solve at least some of the problems related to the industries becoming sick.

\section{Training \& Safety measures}

Following proper work related training/ continuous education methods and observing proper safety and health measures might be helpful in minimizing costs. According to F. W. Taylor, the Management guru, it is desired to apply scientific methods and also to eliminate thumb rules in production and in other decision making 
for efficiency and productivity improvement.

\section{REMEDIAL MEASURES TO PREVENT SICKNESS}

Occurrence of industries becoming sick might come up at various phases of business cycle. Although survival of the fittest is a very much well known proverb, but here in Bangladesh the problem of industries becoming sick cannot be left over to the market forces only as it will bring down adverse repercussions to the national economy. Moreover, sick industries might also become responsible for many social problems particularly in a developing or underdeveloped country. The following measures can be considered for combating the problem of industries becoming sick:

1) Elimination or trying to eliminate the causes which have been described earlier,

2) Cooperation of financial institutions in giving and recovering loans and interest, in arranging easier and acceptable loan disbursing policy and supply of working capital,

3) Favorable government policy with respect to import, export, project appraisal, tariff, etc,

4) Assurance of the uninterrupted power, water and gas supply and raw material supply to the industries,

5) Proper market planning through accurate forecasting and customer survey,

6) Controlling some of the environmental factors like labor unrest, strikes, political instability, etc,

7) Appropriate government policy to save the industries of the country, etc.

8) Proper application of scientific methods of Production Planning \& Control

\section{CONCLUSION}

It will not be over-emphasized to say that industrialization and development of a county are closely related. Industries are established with a view to produce surplus. But there are many instances of industries becoming sick at some point of their life cycle. Although, such examples are many in under-developed and developing countries, it cannot be said that no such examples are found in developed countries too. In this paper an attempt has been made to identify the causes of industries becoming sick and to show how far the application of the theories and principles of Management, Production and Operations Management, and Technology Management plays a role in the prevention of industries becoming sick.

In this paper conditions of 10 industries of different Sector Corporations of Bangladesh have been analyzed. Analysis of graphs as have been shown in this paper and also from the data given in appendix and also that is available in related reports, we can conclude that causes of decline in Industry performance or revenue earning in most of the industries studied may be attributed mostly to the internal causes relating to the improper application of Production Planning And Control methodologies and improper application of the tested and standard management methods like the following :

controlling inventory and over employment; effective marketing policy; cost determination by scientific methods; ensuring energy (gas, electricity), and raw material supply; maintaining long term uniform and steady Government industrial policy; providing easy bank loan policy at least during developing stage; following proper project planning and appraisal methods; making proper human resource planning for at least for employment, work related training, education and safety; etc.,. Besides, we think, political stability is also needed and BMRE (Balancing, Modernization, Rehabilitation \& Expansion) steps might also be practiced in old industries/machines.

\section{REFERENCES}

1. Report submitted by the "Sick Industries and Rehabilitation and Revival cell', Ministry of Industries, Government of Bangladesh, 1992.

2. Dey, Ranjit Kumar, 1989, "Introduction of new Elements of cost to the method of Industrial prices in Bangladesh', Chittagong University Studies, On Commerce, Vol. 5, page 327.

3. Decision: Special Issue on Industrial Sickness, J. of Indian Institute of Management, Vol.6, No. 1, January 1979.

4. "Main paper on Sick Industries: Causes, Remedies and Prevention', web-site: EPP Sick \% 20 industries [1], html, and page 14 .

5. Alam, S.M. Jahirul: "Industrial Rehabilitation Strategy Paper, Bangladesh", Prepared for the Ministry of Industries, August, 2003.

6. MIS Report, BSEC, 1998-99, 99-2000, 2000- 01

7. Krajewski, "Production and Operations Management', Addision Wesly, 1993.

8. M, Christopher, "Logistic and Supply Chain Management', Pearson Education, 2005.

9. Azim, M. Anwarul, "Technology Management and Development of Nations", UGC, Bangladesh. 10. Chase and Aqualino, "Production and Operations Management", Addison Wesley, 1993.

11. MIS report, BSEC, 1986-87,1987-88,199091,1991-92, 1992-93.1993-94 and so on.

12. Annual report, BCIC, 2004-05. 


\section{Appendix 1}

Production \& Sales Data of Chittagong Steel Mills Limited $^{11}$

( Taka: Crore )

\begin{tabular}{|c|c|c|}
\hline Financial Year & Production & Sales \\
\hline $1989-90$ & 163.91 & 158.61 \\
\hline $1990-91$ & 123.90 & 116.76 \\
\hline $1991-92$ & 73.89 & 49.46 \\
\hline $1992-93$ & 48.55 & 56.89 \\
\hline $1993-94$ & 47.84 & 44.11 \\
\hline $1994-95$ & 78.59 & 63.71 \\
\hline $1995-96$ & 59.20 & 57.29 \\
\hline $1996-97$ & 70.01 & 45.89 \\
\hline $1997-98$ & 33.85 & 38.97 \\
\hline $1998-99$ & 31.17 & 18.85 \\
\hline
\end{tabular}

\section{Appendix 2}

Production \& Sales Data of Bangladesh Machine Tools Factory ${ }^{11}$

( Taka : Crore )

\begin{tabular}{|c|c|c|}
\hline Financial Year & Production & Sales \\
\hline $1986-87$ & 9.03 & 6.43 \\
\hline $1987-88$ & 13.68 & 12.70 \\
\hline $1988-89$ & 14.70 & 14.95 \\
\hline $1989-90$ & 18.17 & 18.43 \\
\hline $1990-91$ & 10.39 & 12.18 \\
\hline $1991-92$ & 7.06 & 6.20 \\
\hline $1992-93$ & 5.25 & 7.02 \\
\hline $1993-94$ & 6.65 & 8.17 \\
\hline
\end{tabular}

